\title{
Preliminary investigations of in vitro antioxidant, antityrosinase, acetylcholinesterase and anti-inflammatory activities of Actinodaphne species
}

Wan Mohd Nuzul Hakimi Wan SALLEH, Farediah AHMAD

\begin{abstract}
The purpose of this study was to investigate the biological activities of extracts from two Actinodaphne species from Malaysia, which are Actinodaphne macrophylla and Actinodaphne pruinosa. The in vitro activity studies were assessed for their antioxidant, antityrosinase, acetylcholinesterase and anti-inflammatory activities. The methanolic bark extract of $A$. pruinosa have shown the highest activity on $\mathrm{DPPH}^{\cdot}\left(\mathrm{IC}_{50}: 70.2 \mu \mathrm{g} / \mathrm{mL}\right)$, $\mathrm{ABTS}^{\cdot+}\left(\mathrm{IC}_{50}: 147.2 \mu \mathrm{g} / \mathrm{mL}\right)$ and phenolic content (55.1 mg gallic acid/g), while the bark extracts of $A$. macrophylla showed the
\end{abstract}

best inhibitory activity against mushroom tyrosinase (I: 45.2\%) and lipoxygenase (I: 69.2\%) assays. All extracts have shown strong AChE inhibitory activity (I: 70.5-88.1\%), comparable to galantamine (I: 95.9\%). The isolation of specific bioactive compounds as well as evaluating their safety may be necessary in the exploration of these species for potential new therapeutic drugs or drug leads.

Keywords: Actinodaphne, antioxidant, antityrosinase, acetylcholinesterase, anti-inflammatory
Wan Mohd Nuzul Hakimi Wan Salleh

Department of Chemistry, Faculty of Science, Universiti Teknologi Malaysia (UTM), 81310 Skudai, Johor, Malaysia.

Farediah Ahmad

Department of Chemistry, Faculty of Science, Universiti Teknologi Malaysia (UTM), 81310 Skudai, Johor, Malaysia.

\author{
Corresponding author: \\ Farediah Ahmad \\ E-mail:farediah@kimia.fs.utm.my \\ Tel: +6075534137 \\ Fax: +6075566162
}

Submitted/Gönderilme: 02.02.2016 Accepted/Kabul: 11.03.2016

Revised/Düzeltme: 09.03.2016

\section{INTRODUCTION}

The genus Actinodaphne belongs to the family Lauraceae with about 100 species of evergreen trees and shrubs, occurs mainly in tropical-subtropical Asia and is an important component of tropical forests. They are widely distributed in Malaysia, Indonesia, Eastern Asia and few in North America (1). It is locally known as wuru (Indonesia) or medang kuning and medang kunyit (Malaysia) (2). Some species of the genus are used in traditional medicine for the treatment of several ailments. The decoction of leaves of A. angustifolia is used in kidney trouble due to stone. The leaves of $A$. hookeri are used in the treatment of diabetes, urinary disorders, while the bark of A. obovata is used to treat fractures (3). The root of $A$. lancifolia is a traditional Chinese medicine used for the treatment of stomachache, arthritis, overexertion, and edema (4). This genus have been reported to produce isoquinoline alkaloids (5), lactones (6), lignans (7), and phenolic amides (8). From the literature survey, Actinodaphne species have been reported to have antimicrobial (9), hepatoprotective (10), anti-inflammatory (11), antibacterial (12) and antioxidant (13) activities. Phytochemistry of A. macrophylla has been studied and resulted in the isolation of isoquinoline alkaloids and their antimalarial activities (14). In addition, 
phytochemical study on A. pruinosa were successfully isolated aporphines alkaloids and their cytotoxicity activity (15).

Hence, in the present study, work has been carried out to determine the antioxidant, antityrosinase, acetylcholinesterase and anti-inflammatory activities of the $n$-hexane, ethyl acetate and methanol extracts of A. macrophylla and and A. pruinosa. To the best of our knowledge, this is the first report describing these activities on the species.

\section{MATERIALS AND METHODS}

\section{Plant materials}

The leaves and bark of A. macrophylla (SK2956/16) and A. pruinosa (SK2957/16) were collected from Hutan Simpan
Bangi, Selangor in September 2015, and identified by Dr. Shamsul Khamis from Institute of Biosience (IBS), Universiti Putra Malaysia (UPM). The voucher specimens were deposited at the Herbarium of IBS, UPM.

\section{Extraction method}

The dried and powdered leaves and bark of the above mentioned species (150 g each) were extracted firstly with $n$-hexane (hex), followed by ethyl acetate (EtOAc) and methanol $(\mathrm{MeOH})(500 \mathrm{~mL}$ each). The extracts were filtered and the solvent was removed under vacuum using a rotary evaporator (Eyela, Germany) to obtain the Hex, EtOAc and $\mathrm{MeOH}$ extracts. Percentage yields $(\mathrm{w} / \mathrm{w})$ of all plant extracts obtained are shown in Table 1.

Table 1. Percentage yield and antioxidant activities of two Actinodaphne species

\begin{tabular}{|c|c|c|c|c|c|c|}
\hline Species & Part & Extracts & Yield & $\begin{array}{c}\text { DPPH IC }_{50} \\
(\mu \mathrm{g} / \mathrm{mL})\end{array}$ & $\begin{array}{c}\text { ABTS IC }_{50} \\
(\mu \mathrm{g} / \mathrm{mL})\end{array}$ & $\begin{array}{c}\text { TPC } \\
(\mathrm{mg} \mathrm{GA} / \mathrm{g})\end{array}$ \\
\hline \multirow{6}{*}{$\begin{array}{l}\text { Actinodaphne } \\
\text { macrophylla }\end{array}$} & \multirow[t]{3}{*}{ Leaves } & Hex & $0.82 \mathrm{~g}, 0.54 \%$ & 224.6 & 401.5 & $32.6 \pm 0.5$ \\
\hline & & EtOAc & $1.05 \mathrm{~g}, 0.70 \%$ & 292.5 & 425.2 & $25.4 \pm 0.3$ \\
\hline & & $\mathrm{MeOH}$ & $2.52 \mathrm{~g}, 1.68 \%$ & 196.5 & 352.8 & $38.2 \pm 0.2$ \\
\hline & \multirow[t]{3}{*}{ Bark } & Hex & $1.05 \mathrm{~g}, 0.70 \%$ & 158.2 & 305.1 & $39.5 \pm 0.1$ \\
\hline & & EtOAc & $2.10 \mathrm{~g}, 1.40 \%$ & 122.5 & 240.2 & $41.8 \pm 0.2$ \\
\hline & & $\mathrm{MeOH}$ & $3.21 \mathrm{~g}, 2.14 \%$ & 92.5 & 186.4 & $54.1 \pm 0.1$ \\
\hline \multirow{6}{*}{$\begin{array}{l}\text { Actinodaphne } \\
\text { pruinosa }\end{array}$} & \multirow[t]{3}{*}{ Leaves } & Hex & $0.75 \mathrm{~g}, 0.50 \%$ & 251.0 & 395.2 & $29.5 \pm 0.4$ \\
\hline & & EtOAc & $1.85 \mathrm{~g}, 1.23 \%$ & 185.2 & 225.6 & $36.5 \pm 0.1$ \\
\hline & & $\mathrm{MeOH}$ & $2.82 \mathrm{~g}, 1.88 \%$ & 176.8 & 224.5 & $42.8 \pm 0.3$ \\
\hline & \multirow[t]{3}{*}{ Bark } & Hex & $0.92 \mathrm{~g}, 0.61 \%$ & 135.2 & 208.2 & $48.7 \pm 0.2$ \\
\hline & & EtOAc & $1.44 \mathrm{~g}, 0.96 \%$ & 95.4 & 180.3 & $52.2 \pm 0.2$ \\
\hline & & $\mathrm{MeOH}$ & $2.42 \mathrm{~g}, 1.61 \%$ & 70.2 & 147.2 & $55.1 \pm 0.1$ \\
\hline BHT & & & & 18.5 & 52.2 & - \\
\hline
\end{tabular}

TPC - Total phenolic content; BHT - Butylated hydroxytoluene; GA - gallic acid; I\% - percentage inhibition

\section{Solvents and chemicals}

Analytical grade $n$-hexane, ethyl acetate and methanol used for extraction were purchased from Merck (Germany). Antioxidants: $\beta$-carotene, linoleic acid, 1,1-diphenyl-2-picrylhydrazyl (DPPH), 2,2'-azino-bis(3ethylbenzothiazoline-6-sulphonic acid) (ABTS), potassium persulfate, gallic acid and butylated hydroxytoluene (BHT) were obtained from Sigma-Aldrich (Germany). Analytical grade methanol, ethanol and dimethylsulfoxide (DMSO), HPLC grade chloroform, Folin-Ciocalteu's reagent, anhydrous sodium sulfate, sodium carbonate and polyoxyethylene sorbitan monopalmitate (Tween-40) were purchased from Merck (Germany). Antityrosinase: Mushroom tyrosinase enzyme (EC1.14.18.1), kojic acid and L-dopa were purchased from Sigma-Aldrich (Germany). Acetylcholinesterase: Electric eel AChE (Type-VI-S, EC 3.1.1.7), acetylcholine iodide, 5,5'-dithiobis (2-nitrobenzoic acid) $99 \%$ (DTNB), and galantamine were purchased from Sigma-Aldrich (Germany). Anti-inflammatory: Lipoxygenase inhibitor screening assay kit (Item No. 760700 Cayman Chemicals Co) was purchased from i-DNA Biotechnology (M) Sdn. Bhd. (Malaysia). 


\section{Antioxidant activities}

\section{Total Phenolic Content (TPC)}

Total phenolic contents of the extracts were determined by gallic acid equivalent (16). A sample of stock solution (1.0 $\mathrm{mg} / \mathrm{mL}$ ) was diluted in $\mathrm{MeOH}$ to final concentrations of $1000 \mu \mathrm{g} / \mathrm{mL}$. A $0.1 \mathrm{~mL}$ aliquot of sample was pipetted into a test tube containing $0.9 \mathrm{~mL}$ of methanol, then $0.05 \mathrm{~mL}$ FolinCiocalteu's reagent was added, and the flask was thoroughly shaken. After $3 \mathrm{~min}, 0.5 \mathrm{~mL}$ of $5 \% \mathrm{Na}_{2} \mathrm{CO}_{3}$ solution was added and the mixture was allowed to stand for $2 \mathrm{~h}$ with intermittent shaking. Then, $2.5 \mathrm{~mL}$ of methanol was added and left to stand in the dark for $1 \mathrm{~h}$. The absorbance measurements were recorded at $765 \mathrm{~nm}$. The same procedure was repeated for the standard gallic acid solutions. The concentration of total phenolic compounds in the extracts was expressed as $\mathrm{mg}$ of gallic acid equivalent per gram of sample. Tests were carried out in triplicate and the gallic acid equivalent value was reported as mean $\pm \mathrm{SD}$ of triplicate.

\section{DPPH Radical scavenging}

The free radical scavenging activity was measured by the DPPH method with minor modifications (17). Briefly, 0.1 $\mathrm{mM} \mathrm{DPPH}^{*}(1 \mathrm{~mL})$ dissolved in EtOH was added to an $\mathrm{EtOH}$ solution $(3 \mathrm{~mL})$ of the tested samples and standard (BHT) at different concentrations $(200,150,100,50,25 \mu \mathrm{g} / \mathrm{mL})$. An equal volume of EtOH was added in the control test. The mixture was shaken vigorously and allowed to stand at room temperature for $30 \mathrm{~min}$. Then the absorbance at $517 \mathrm{~nm}$ was measured with a UV-vis spectrophotometer. The percent inhibitions (I\%) of DPPH radical were calculated as follow:

$$
\mathrm{I} \%=\left[\mathrm{A}_{\text {blank }}-\mathrm{A}_{\text {sample }} / \mathrm{A}_{\text {blank }}\right] \times 100
$$

where $A_{\text {blank }}$ is the absorbance value of the control reaction (containing all reagents except the test extracts) and $\mathrm{A}_{\text {sample }}$ is the absorbance values of the test extracts/standard. The sample concentration providing 50\% inhibition $\left(\mathrm{IC}_{50}\right)$ was calculated by plotting inhibition percentages against concentrations of the sample. All tests were carried out in triplicate and $\mathrm{IC}_{50}$ values were reported as means $\pm \mathrm{SD}$ of triplicates.

\section{ABTS radical scavenging}

The antioxidant capacity was estimated in terms of the ABTS $\bullet+$ radical scavenging activity following the previously method (18). Briefly, ABTS was obtained by reacting 14 mM ABTS ${ }^{+}$stock solution $(5 \mathrm{~mL})$ with $4.9 \mathrm{mM}$ potassium persulfate $(5 \mathrm{~mL})$ and the mixture was left to stand in the dark at room temperature for $12-16 \mathrm{~h}$ before use. The
ABTS solution (stable for 2 days) was diluted with distilled water to an absorbance at $734 \mathrm{~nm}$ of $0.70 \pm 0.02$ by UV-vis spectrophotometer. After the addition of $15 \mu \mathrm{L}$ of extracts (concentration of $200,150,100,50,25 \mu \mathrm{g} / \mathrm{mL}$ ) to $285 \mu \mathrm{L}$ of diluted $\mathrm{ABTS}^{\circ+}$ solution, the absorbance was measured after $30 \mathrm{~min}$. The same procedure was repeated for the standard gallic acid solutions. The percentage inhibition (I\%) of ABTS ${ }^{++}$ radical-scavenging activity of the extracts was expressed as:

$$
\mathrm{I} \%=\left[\mathrm{A}_{\text {control }}-\mathrm{A}_{\text {sample }} / \mathrm{A}_{\text {control }}\right] \times 100
$$

where $A_{\text {control }}$ is the absorbance of the blank control (ABTS solution without extracts) and $\mathrm{A}_{\text {sample }}$ is the absorbance of the extracts. All tests were carried out in triplicate and $\mathrm{IC}_{50}$ values are reported as means \pm SD of triplicates.

\section{Antityrosinase activity}

Tyrosinase inhibition assay was performed according to the previously method with slight modifications (19). Briefly, the extracts and kojic acid were dissolved in DMSO prepared as $1 \mathrm{mg} / \mathrm{mL}$. The reaction was carried out using 96-well microplate and microplate reader (Epoch MicroVolume Spectrophotometer, USA) was used to measure the absorbance at $475 \mathrm{~nm}$. $40 \mu \mathrm{L}$ of extracts dissolved in DMSO with $80 \mu \mathrm{L}$ of phosphate buffer (pH 6.8), $40 \mu \mathrm{L}$ of tyrosinase enzyme and $40 \mu \mathrm{L}$ of L-dopa were put in each well. Each sample was accompanied by a blank that had all the components except for L-dopa. Kojic acid was used as reference standard inhibitor for comparison. The percentage of tyrosinase inhibition (I\%) was calculated as follows:

$$
\mathrm{I} \%=\left[\mathrm{A}_{\text {control }}-\mathrm{A}_{\text {sample }} / \mathrm{A}_{\text {control }}\right] \times 100
$$

where $A_{\text {control }}$ is the absorbance of the control reaction and $\mathrm{A}_{\text {sample }}$ is the absorbance of the extracts/reference. Analyses were expressed as means $\pm \mathrm{SD}$ of triplicates.

\section{Acetylcholinesterase (AChE) activity}

AChE inhibitory activity of the extracts was measured by slightly modifying the spectrophotometric method (20-21). Electric eel AChE was used, while acetylthiocholine iodide (AChI) was employed as the substrate of the reaction. DTNB acid was used for the measurement of the AChE activity. Briefly, $140 \mu \mathrm{L}$ of sodium phosphate buffer ( $\mathrm{pH} 8.0$ ), $20 \mu \mathrm{L}$ of DTNB, $20 \mu \mathrm{L}$ of test compounds and $20 \mu \mathrm{L}$ of AChE solution were added by multichannel automatic pipette in a 96-well microplate and incubated for $15 \mathrm{~min}$ at $25^{\circ} \mathrm{C}$. The reaction was then initiated with the addition of $10 \mu \mathrm{L}$ of AChI. Hydrolysis of AChI was monitored by the formation of the yellow 5-thio-2-nitrobenzoate anion as a result of the reaction of DTNB with thiocholines, catalyzed by enzymes at $412 \mathrm{~nm}$ utilizing a 96-well microplate reader (Epoch Micro-Volume Spectrophotometer, USA). Percentage of inhibition (I\%) of 
AChE was determined by comparison of rates of reaction of samples relative to blank sample (EtOH in phosphate buffer $\mathrm{pH}=8$ ) using the formula:

$$
\mathrm{I} \%=[\mathrm{E}-\mathrm{S} / \mathrm{E}] \times 100 ;
$$

where $\mathrm{E}$ is the activity of enzyme without test sample and $\mathrm{S}$ is the activity of enzyme with test sample. The experiments were done in triplicate. Galantamine was used as the positive controls.

\section{Anti-inflammatory activity}

Lipoxygenase (LOX) inhibition was determined using an enzyme immuno assay (EIA) kit (Catalog No. 760700, Cayman Chemical, USA) according to the manufacturer's instructions and previous study (22). The Cayman Chemical lipoxygenase inhibitor screening assay detects and measures the hydroperoxides produced in the lipoxygenation reaction using a purified lipoxygenase. Stock solutions of the extracts were dissolved in a minimum volume of DMSO and were diluted using the supplied buffer solution $(0.1 \mathrm{M}$, Tris- $\mathrm{HCl}$, $\mathrm{pH}$ 7.4). To a $90 \mu \mathrm{L}$ solution of 5-LOX enzyme in $0.1 \mathrm{M}$, Tris- $\mathrm{HCl}$, and $\mathrm{pH} 7.4$ buffer, $10 \mu \mathrm{L}$ of various concentrations of test samples (final volume of $210 \mu \mathrm{L}$ ) were added and the lipoxygenase reaction was initiated by the addition of $10 \mu \mathrm{L}(100 \mu \mathrm{M})$ of arachidonic acid. After maintaining the 96-well plates on a shaker for $5 \mathrm{~min}, 100 \mu \mathrm{L}$ of chromogen was added and the plate was retained on a shaker for $5 \mathrm{~min}$. The lipoxygenase activity was determined after measuring absorbance at a wavelength of $500 \mathrm{~nm}$. The percentage inhibition (I\%) of the extracts was calculated as follows:

$$
\mathrm{I} \%=\left[\mathrm{A}_{\text {initial activity }}-\mathrm{A}_{\text {inhibitor }} / \mathrm{A}_{\text {initial activity }}\right] \times 100
$$

where $A_{\text {initial activity }}$ is the absorbance of $100 \%$ initial activity wells without sample and $A_{\text {inhibitor }}$ is the absorbance of extracts/reference. All tests were carried out in triplicate and expressed as means $\pm \mathrm{SD}$.

\section{Statistical analysis}

Data obtained from biological activities were expressed as mean values. The statistical analyses were carried out by employing one way ANOVA $(\mathrm{p}<0.05)$. A statistical package (SPSS version 11.0) was used for the data analysis.

\section{RESULTS AND DISCUSSION}

A number of methods and variations have been developed and applied for the assessment of antioxidant capacity. Thus, we applied several antioxidant assays that would provide a better insight into the true antioxidant potential of the extracts. They were DPPH radical scavenging, ABTS radical scavenging and total phenolic content. The antioxidant activity of Actinodaphne species is summarised in Table 1 . In the $\mathrm{DPPH}^{\cdot}$ assay, the $\mathrm{MeOH}$ bark extracts of $A$. macrophylla and $A$. pruinosa were found to be good radical scavengers with $\mathrm{IC}_{50}$ values of 70.2 and $92.5 \mu \mathrm{g} / \mathrm{mL}$, respectively. However, these values were lower than the positive control, BHT which showed $\mathrm{IC}_{50}$ value of $18.5 \mu \mathrm{g} / \mathrm{mL}$. Both extracts were also found to have the highest TPC (A. pruinosa 55.1 mg GA/g; A. macrophylla $54.1 \mathrm{mg} \mathrm{GA} / \mathrm{g}$ ) among others. The $\mathrm{MeOH}$ and EtOAc bark extracts of A. pruinosa have showed the highest radical scavenging activity in the ABTS assay with IC $_{50}$ values 147.2 and $180.3 \mu \mathrm{g} / \mathrm{mL}$, respectively, followed by the $\mathrm{MeOH}$ bark extracts of $A$. macrophylla with $\mathrm{IC}_{50}$ of 186.4 $\mu \mathrm{g} / \mathrm{mL}$. Over all, in the present analysis, a strong correlation was established among the TPC, DPPH ${ }^{\cdot}$ and $\mathrm{ABTS}^{*}$ assays. The $\mathrm{MeOH}$ extracts showed the highest antioxidant activity in all assays compared to other extracts. These results are in line with the previous finding (23) which reported that extracts with higher TPC also showed strong activity against DPPH: Most of the antioxidant potential of medicinal plants is due to the redox properties of phenolic compounds, which enable them to act as reducing agents, hydrogen donors and singlet oxygen scavengers (24). Prajapati et al (13), have reported that the leaves extract $A$. hookeri displayed potent antioxidant properties against $\beta$-carotene-linoleic acid $\left(\mathrm{IC}_{50}\right.$ of $194.16 \mu \mathrm{g} / \mathrm{mL}$ ), lipid peroxidation $\left(\mathrm{IC}_{50}\right.$ of $51.71 \mu \mathrm{g} / \mathrm{mL}$ ) and total antioxidant capacity ( $290 \mu \mathrm{g}$ ascorbic acid/mg). Akki et al (25), reported that the alcoholic and chloroform leaves extracts of $A$. hookeri showed significant antioxidant activity by increasing the decreased levels of antioxidant enzymes such as superoxide dismutase, catalase, and reduced glutathione and decreasing the lipid peroxidation state.

In the current study, antityrosinase, acetylcholinesterase and 15-LOX inhibiting activity were analysed using mushroom tyrosinase, AChE enzyme and 15-lipoxygenase enzyme, respectively. Table 2 summarises the results of inhibition percentage at the concentration of $1 \mathrm{mg} / \mathrm{mL}$. Tyrosinase inhibitors are chemical agents capable of reducing enzymatic reactions, such as food browning and melanisation of human skin. Therefore, these agents have good commercial potential in both food processing and cosmetic industries. All extracts showed weak inhibitory activity with the percentage inhibition in the range of $30.8-45.2 \%$. The $\mathrm{MeOH}$ bark extract of A. macrophylla displayed the highest tyrosinase inhibition activity which gave $45.2 \%$ inhibition, followed by the leaves of A. pruinosa extracts with $44.6 \%$. These results 
are lower than that of kojic acid which revealed inhibition of $97.1 \%$. The inhibition of tyrosinase might depend on the hydroxyl groups of phenolic compounds of the mushroom extracts that could form a hydrogen bond to active site of the enzyme, leading to a lower enzymatic activity. Some tyrosinase inhibitors act through hydroxyl groups that bind to the active site on tyrosinase, resulting in steric hindrance or change in conformation. Phenolic acids and flavonoids proved to be effective inhibitors of tyrosinase activity such as gallic acid and (-)-epicatechin (26-27).

Table 2. Antityrosinase, acetylcholinesterase and anti-inflammatory activities of two Actinodaphne species

\begin{tabular}{|c|c|c|c|c|c|}
\hline Species & Part & Extracts & $\begin{array}{l}\text { Antityrosinase } \\
\text { (I\%) }\end{array}$ & $\begin{array}{c}\text { Acetylcholinesterase } \\
\text { (I\%) }\end{array}$ & $\begin{array}{c}\text { Anti-inflammatory } \\
\text { (I\%) }\end{array}$ \\
\hline \multirow{6}{*}{$\begin{array}{l}\text { Actinodaphne } \\
\text { macrophylla }\end{array}$} & \multirow[t]{3}{*}{ Leaves } & Hex & $35.2 \pm 1.3$ & $78.5 \pm 1.2$ & $35.2 \pm 1.2$ \\
\hline & & EtOAc & $33.5 \pm 1.5$ & $75.2 \pm 1.1$ & $42.8 \pm 1.4$ \\
\hline & & $\mathrm{MeOH}$ & $32.5 \pm 1.1$ & $80.2 \pm 1.1$ & $40.5 \pm 1.2$ \\
\hline & \multirow[t]{3}{*}{ Bark } & Hex & $34.2 \pm 0.2$ & $85.2 \pm 0.2$ & $52.2 \pm 0.1$ \\
\hline & & EtOAc & $35.4 \pm 0.2$ & $83.8 \pm 0.2$ & $56.5 \pm 0.3$ \\
\hline & & $\mathrm{MeOH}$ & $45.2 \pm 0.1$ & $88.1 \pm 0.1$ & $69.2 \pm 0.2$ \\
\hline \multirow{6}{*}{$\begin{array}{l}\text { Actinodaphne } \\
\text { pruinosa }\end{array}$} & \multirow[t]{3}{*}{ Leaves } & Hex & $42.6 \pm 0.4$ & $72.5 \pm 0.3$ & $32.5 \pm 0.1$ \\
\hline & & EtOAc & $43.2 \pm 0.3$ & $70.5 \pm 0.5$ & $30.2 \pm 0.1$ \\
\hline & & $\mathrm{MeOH}$ & $44.6 \pm 0.2$ & $75.8 \pm 0.2$ & $40.8 \pm 0.4$ \\
\hline & \multirow[t]{3}{*}{ Bark } & Hex & $35.4 \pm 1.3$ & $84.1 \pm 0.1$ & $50.5 \pm 0.1$ \\
\hline & & EtOAc & $30.8 \pm 1.3$ & $83.5 \pm 0.2$ & $52.5 \pm 0.4$ \\
\hline & & $\mathrm{MeOH}$ & $36.2 \pm 1.2$ & $85.1 \pm 0.2$ & $60.2 \pm 0.2$ \\
\hline Kojic acid & & & $97.1 \pm 0.1$ & - & - \\
\hline Galantamine & & & - & $95.9 \pm 0.2$ & - \\
\hline Quercetin & & & - & - & $89.1 \pm 0.2$ \\
\hline
\end{tabular}

Data represent as mean \pm SD of three independent experiments; I\% - percentage inhibition

In acetylcholinesterase activity, all extracts have found to have strong activity, in the range of $70.5-88.1 \%$, comparable to galantamine, $95.9 \%$. The $\mathrm{MeOH}$ bark and leaves extract of A. macrophylla exerted the highest AChE activity with inhibition of $88.1 \%$ and $85.2 \%$, respectively. In addition, for A. pruinosa, the $\mathrm{MeOH}$ bark extract found to have significant inhibition, $85.1 \%$ followed by their hexane $(84.1 \%)$ and EtOAc (83.5\%) extracts. Inhibition of AChE, the key enzyme in the breakdown of acetylcholine, is considered as one of the treatment strategies against several neurological disorders such as Alzheimer disease (28). Since the most strong synthetic or natural product driven AChE inhibitors are known to contain nitrogen, the promising activity of both Actinodaphne extracts could be due to their high alkaloidal contents (29-30). These results were in accordance with the previous phytochemical studies of both species, which found to have alkaloids as their major compounds (14-15).

Lipoxygenases are the key enzymes in the biosynthesis of leukotrienes that play an important role in several inflammatory diseases. Inhibition of LOX may influence the inflammation processes and thus be of interest for modulation of the lipoxygenase pathway. Therefore, inhibitors of oxidative stress and LOX have been considered as therapeutically useful in the treatment of many related diseases such as liver disease, arthritis and cancer (31). According to Table 2, a standard lipoxygenase inhibitory chemical, quercetin, inhibited lipoxygenase activity by $89.1 \%$ at $1 \mathrm{mg} / \mathrm{mL}$. The $\mathrm{MeOH}$ bark extracts of $A$. macrophylla and A. pruinosa exhibited moderate lipoxygenase inhibitory effect of $69.2 \%$ and $60.2 \%$, respectively. It is noteworthy that, the $\mathrm{MeOH}$ bark extracts of A. macrophylla and A. pruinosa had the highest TPC with good antioxidant activity, a finding which is consistent with a previous study which found a relationship between the anti-inflammatory activity and the presence of polyphenols (32). Antioxidants are also known to inhibit plant lipoxygenases. Studies have implicated that oxygen free radicals in the process of inflammation and phenolic compounds may block the cascade process of arachidonic acid metabolism by inhibiting lipoxygenase activity and serve as a scavenger of reactive free radicals that are produced during arachidonic acid metabolism (33-34). 


\section{CONCLUSION}

We have herein screened the leaves and bark extracts of $A$. macrophylla and A. pruinosa of Malaysian origin for their enzyme (AChE, tyrosinase, 15-LOX) inhibitory potentials as well as antioxidant activity of $n$-hexane, ethyl acetate and methanol extracts. The results revealed that all extracts from both A. macrophylla and A. pruinosa have significant activity as AChE inhibitors but inactive towards antityrosinase and weak activity against 15-LOX. In addition, all extracts were also found to have low antioxidant capacity except the methanol extract of bark of A. pruinosa in the assay used.

Actinodaphne türlerinin in vitro antioksidan, antitirozinaz, antikolinesteraz ve antienflamatuvar etkilerinin araştırılması

\section{ÖZET}

Bu çalışmanın amacı Malezyadda yetişen iki Actinodaphne türünün; Actinodaphne macrophylla ve Actinodaphne pruinosa'nın biyolojik etkilerinin araştırılmasıdır. In vitro deneysel yöntemler kullanılarak Actinodaphne macrophylla ve Actinodaphne pruinosa'nın antioksidan, antitirozinaz, antikolinesteraz ve antienflamatuvar etki potansiyelleri araştırılmıştır. A. pruinosa'nın metanolik kabuk ekstresi DPPH (İK $\left.{ }_{50}: 70.2 \mu \mathrm{g} / \mathrm{mL}\right)$, ABTS (İK ${ }_{50}$
Although, phytochemical investigation has been carried out by other researchers before, but this is the first report on in vitro bioactivity studies on the extracts of A. macrophylla and $A$. pruinosa. In addition, further studies also needed to evaluate the in vivo activity in animal model.

\section{ACKNOWLEDGEMENTS}

The authors are grateful to Research University Grant (GUP), under vote Q.J130000.2526.03H93 for financial support and Department of Chemistry, Faculty of Science, Universiti Teknologi Malaysia for research facilities.

\section{REFERENCES}

1. Purkayastha SK. Indian woods. Their identification, properties and uses. Vol. V. Oleaceae to Santalaceae. The controller of publications, Delhi. 1985.

2. Burkill IH. Dictionary of the economic products of the Malay Peninsula, Ministry of Agriculture Malaysia: Kuala Lumpur, Malaysia. 1966.

3. Sharma M. Comparative wood anatomy of Actinodaphne species.International. J P Anim Environ Sci 2014; 4: 165-9.

4. Kim CM, Shin MK, Lee KS, Ahn DK. Chinese Medicine Dictionary. Jungdam Co 1998; 6: 3398.

5. Uprety H, Bhakuni DS, Dhar MM. Aporphinealkaloids of Litsea sebifera, L. Wightiana and Actinodaphne obovata. Phytochemistry 1972; 11: 3057-9.

6. Tanaka H, Nakamura $\mathrm{T}$, Ichino $\mathrm{K}$, Ito $\mathrm{K}$. Two lactonic compounds, lancifolide and isolancifolide from Actinodaphne lancifolia. Phytochemistry 1989; 28: 626-8.

7. Tanaka H, Nakamura T, Ichino K, Ito K. A lignan from Actinodaphne longifolia. Phytochemistry 1989; 28: 952-4.

8. Tanaka H, Nakamura T, Ichino K, Ito K. A phenolic amide from Actinodaphne longifolia. Phytochemistry 1989; 28: 25167.

9. Vimal S, Rajesh Kumar S. Preliminary phytochemical and antimicrobial studies on the leaf extracts of Actinodaphne lanata Meissner. Int J Pharma Sci Res 2015; 6: 1200-5.

10. Saravanan D, Thirumalai D, Asharani IV. Evaluation of
$147.2 \mu \mathrm{g} / \mathrm{mL}$ ) analizlerinde en yüksek etkiyi gösteririken fenolik içeriği $55.1 \mathrm{mg}$ gallik asit/g olarak bulunmuştur. A. macrophylla'nın kabuk ekstreleri ise mantar tirozinaz (\% 45.2) ve lipooksijenaz (\% 69.2) analizlerinde en yüksek etkiyi göstermiştir. Bütün ekstrelerin, galantamin'le (\%95.9) karşılaştırıldığında yüksek AChE inhibitörü etki gösterdiği (\%70.5-88.1) bulunmuştur. Çalışmaya dahil edilen Actinodaphne türlerinin biyoaktif bileşenlerinin izole edilmesi ve bu bileşenlerin güvenilirliğinin gösterilmesi bahsi geçen Actinodaphne türlerinin potansiyel ilaç öncü bileşikleri olarak gösterilebilmesi için gereklidir.

Anahtar kelimeler: Actinodaphne, antioksidan, antirozinaz, asetilkolinesteraz, antienflamatuvar phytonutrients, mineral composition, antimicrobial and hepatoprotective activities of leaves of Actinodaphne madraspatana Bedd (Lauraceae). J Chem Pharm Res 2015; 7: 312-20.

11. Kim Y, Min HY, Park HJ, Lee EJ, Park EJ, Hwang HJ, Jin C, Lee YS, Lee SK. Suppressive effect of inducible nitric oxide synthase (iNOS) expression by the methanol extract of Actinodaphne lancifolia. Phytother Res 2004; 18: 853-6.

12. Vimal S, Rajesh Kumar S. Antibacterial activity of root bark extract of Actinodaphne lanata Meissner. Int J Res Pure Appl Microbiol 2014; 4: 43-5.

13. Prajapati D, Patel N, Mruthunjaya K, Savadi R. Antioxidant activity of Actinodaphne hookeri Meissn leaves. J Sci Res 2009; 3: 606-14.

14. Fadaeinasab M, Taha H, Fauzi PNM, Ali HM, Widyawaruyanti A. Anti-malarial activity of isoquinoline alkaloids from the stem bark of Actinodaphne macrophylla. Nat Prod Commun 2015; 10: 1541-2.

15. Rachmatiah T, Mukhtar MR, Nafiah MA, Hanafi M, Kosela S, Morita H, Litaudon M, Awang K, Omar H, Hadi AHA. (+)-N-(2-Hydroxypropyl)lindcarpine: A new cytotoxic aporphine isolated from Actinodaphne pruinosa Nees. Molecules 2009; 14: 2850-6.

16. Salleh WMNHW, Ahmad F and Khong HY. Chemical compositions and biological activities of the essential oils of Beilschmiedia madang Blume (Lauraceae). Arch Pharm Res 2015; 38: 485-93. 
17. Shimada K, Fujikawa $\mathrm{K}$, Yahara $\mathrm{K}$ and Nakamura $\mathrm{T}$. Antioxidative properties of xanthine on autoxidation of soybean oil in cyclodextrin emulsion. J Agric Food Chem 1992; 40: 945-8.

18. Re R, Pellegrin N, Proteggente A, Pannala A, Yang M and Rice-Evans C. Antioxidant activity applying an improved ABTS radical cation decolorization assay. Free Radic Biol Med 1999; 26: 1231-7.

19. Masuda T, Yamashita D, Takeda Y, Yonemori S. Screening for tyrosinase inhibitors among extracts of seashore plants and identification of potent inhibitors from Garcinia subelliptica. Biosci Biotech Biochem 2005; 69: 197-201.

20. Ellman GL, Courtney KD, Andres V, Feather-Stone RM. A new and rapid colorimetric determination of acetylcholinesterase activity. Biochem Pharmacol 1961; 7: 88-95.

21. Orhan I, Aslan S, Kartal M, Sener B, Baser KHC. Inhibitory effect of Turkish Rosmarinus officinalis L. on acetylcholinesterase and butyrylcholinesterase enzymes. Food Chem 2008; 108: 663-8.

22. Salleh WMNHW, Ahmad F, Khong HY, Zulkifli RM. Chemical compositions and biological activities of essential oils of Beilschmiedia glabra. Nat Prod Commun 2015; 10: 1297-1300.

23. Velioglu SG, Gao L, Oomah BD. Antioxidant activity and total phenolics in selected fruits, vegetables, and grain products. J Agric Food Chem 1998; 46: 4113-7.

24. Robards K, Prenzler PD, Tucker G, Swatsitang P, Glover W. Phenolic compounds and their role in oxidative processes in fruits. Food Chem. 1999; 66: 401-36.

25. Akki KS, Krishnamurthy G, Naik HSB. Hepatoprotective and antioxidant effect of Actinodaphne hookeri Meissn. Leaf extracts against $\mathrm{CCl}_{4}$ induced liver injury in rats. Ind $\mathrm{J}$ Nat Prod Resour 2014; 5: 313-9.

26. Momtaz S, Mapunya BM, Houghton PJ, Edgerly C, Hussein A, Naidoo S, Lall N. Tyrosinase inhibition by extracts and constituents of Sideroxylon inerme L. stem bark, used in South
Africa for skin lightening. J Ethnopharmacol 2008; 119: 507-12.

27. Alam N, Yoon KN, Lee KR, Kim HY, Shin PG, Cheong JC, Yoo YB, Shim MJ, Lee MW, Lee TS. Assessment of antioxidant and phenolic compound concentrations as well as xanthine oxidase and tyrosinase inhibitory properties of different extracts of Pleurotus citrinopileatus fruiting bodies. Mycobiol 2011; 39: 12-9.

28. Zarotsky V, Sramek JJ, Culter NR. Galanthamine hydrobromide: an agent for Alzheimer's disease. Am J HealthSystem Pharmacist 2003; 60: 446-52.

29. Martinez A, Castro A. Novel cholinesterase inhibitors as future effective drugs for the treatment of Alzheimer's disease. Expert Opin Invest Drugs 2006; 15: 1-12.

30. Mukherjee PK, Kumar V, Mal M, Houghton PJ. Acetylcholinesterase inhibitors from plants. Phytomedicine 2007; 14: 289-300.

31. Mehta JL, Rasouli N, Sinha AK, Molavi B. Oxidative stress in diabetes: A mechanistic overview of its effects on atherogenesis and myocardial dysfunction. Int J Biochem Cell Biol 2006; 38 : 794-803.

32. Handoussa H, Hanafi R, Eddiasty I, El-Gendy M, El-Khatib A, Linscheid M, Mahran L, Ayoub N. Anti-inflammatory and cytotoxic activities of dietary phenolics isolated from Corchorus olitorius and Vitis vinifera. J Funct Foods 2013; 5: 1204-16.

33. Lin JK, Tsai SH, Lin-Shiau SY. Anti-inflammatory and antitumor effects of flavonoids and flavanoids. Drugs Fut 2001; 26: 145-57.

34. Trouillas P, Calliste CA, Allais DP, Simon A, Marfak A, Delage C, Duroux JL. Antioxidant, anti-inflammatory and antiproliferative properties of sixteen water plant extracts used in the Limousin countryside as herbal teas. Food Chem 2003; 80: 399-407. 